\title{
Perspectives on Teaching Foreign and International Legal Research
}

\author{
Jean Davis \\ Victoria Szymczak \\ Katherine Topulos \\ Stefanie Weigmann
}

\begin{abstract}
SUMMARY. This article discusses various models for teaching international and foreign legal research. In some law schools, international and foreign legal research is a semester-long course. In other law schools, international and foreign legal research is a component of an advanced legal research seminar or an international law course. Stefanie Weigmann presents an overview of teaching international legal research and describes her experience teaching in various formats. Katherine Topulos outlines some of the resources that are helpful for those who want to begin teaching foreign and international legal research. Jean Davis and Victoria Szymczak discuss teaching techniques and class activities for a semester-long course. [Article copies available for a fee from The Haworth Document Delivery Service: 1-800-342-9678. E-mail address: <getinfo@ haworthpressinc.com> Website: <http://www.HaworthPress. com> (C) 2001 by The Haworth Press, Inc. All rights reserved.]
\end{abstract}

Jean Davis is Reference Librarian, International Law Specialist, and Adjunct Associate Professor of Law at Brooklyn Law School

Victoria Szymczak is Electronic Information Specialist and Adjunct Associate Professor of Law at Brooklyn Law School.

Katherine Topulos is Foreign and International Law Librarian and Lecturing Fellow at Duke University School of Law.

Stephanie Weigmann is Reference Librarian in Foreign and International Law at Harvard Law School. At the time of this writing, she was Reference Librarian at the Pappas Law Library, Boston University Law School.

[Haworth co-indexing entry note]: "Perspectives on Teaching Foreign and International Legal Research." Davis, Jean et al. Co-published simultaneously in Legal Reference Services Quarterly (The Haworth Information Press, an imprint of The Haworth Press, Inc.) Vol. 19, No. 3/4, 2001, pp. 55-69; and: Teaching Legal Research and Providing Access to Electronic Resources (ed: Gary L. Hill, Dennis S. Sears, and Lovisa Lyman) The Haworth Information Press, an imprint of The Haworth Press, Inc., 2001, pp. 55-69. Single or multiple copies of this article are available for a fee from The Haworth Document Delivery Service [1-800-342-9678, 9:00 a.m. - 5:00 p.m. (EST). E-mail address: getinfo@haworthpressinc.com].

(C) 2001 by The Haworth Press, Inc. All rights reserved. 


\title{
TEACHING INTERNATIONAL LEGAL RESEARCH IN A LAW SCHOOL
}

\author{
Stefanie Weigmann
}

The teaching of international law has entered the mainstream of the law school curriculum slowly; indeed its proper role is still being discussed. ${ }^{1}$ The general perception is that students, as future lawyers, would benefit from exposure to international law. The Dean of Southern Methodist University School of Law has said that "[s]ervicing the global community will require new approaches for practicing law and for training lawyers." ${ }^{2}$ International law courses, however, are still moving toward complete acceptance: a recent ABA survey found that while law schools are increasing their offerings, students have not been taking complete advantage of those offerings. ${ }^{3}$ The ABA perspective is that all law students should have some familiarity with both public and private aspects of international law. In the midst of this debate about the teaching of international law, it is hardly surprising that the teaching of international legal research-which involves teaching students about international and foreign legal resources-has been largely ignored.

International legal research is now at the stage traditional legal research was thirty years ago. At that time legal research was taught haphazardly, with much of the instruction taking place informally within the context of orientation to the library. ${ }^{4}$ As traditional legal research instruction entered the formal law school curriculum, such instruction moved outside of the influence of the library. Some believe that legal research should have stayed in the library and should be taught by librarians. Arthur Miller, a Harvard Law School professor and advocate of law librarians, has said librarians should be teaching legal research. ${ }^{5}$ Building on his remarks, I believe that the teaching of international legal research should be the responsibility of librarians and is best situated in the formal curriculum of the law school.

The teaching of international legal research fits naturally into the ambit of libraries with significant international curricula and library holdings. These libraries will have a reference librarian who specializes in international and foreign reference. Students, especially if there is an international journal at the law school, have many questions regarding treaties, United Nations documents, and European Union documents. Most researchers who do not specialize in international law have only a vague idea of how to go about researching an international law topic. ${ }^{6}$ Reference librarians are ideally situated to teach international legal research because they are required to familiarize themselves with the resources available in a library and on the Internet in a systematic way and across many subject areas to help their patrons. At the moment, librarians also appear to be the only group interested in interna- 
tional legal research instruction. Most law school legal research courses never touch any aspect of the sources of international law, including the teaching of treaty research-an important part of U.S. law. Librarians should take the current situation, with librarians as the primary instructors of international legal research, and formalize that role making instruction in this area a permanent part of the role of every foreign and international reference librarian.

A survey of how international legal research is currently taught at various law schools shows a range of instructional models. Many law schools offer subject-specific instruction, such as researching the law of the European Union or researching United Nations documents. These are offered as individual sessions either through the library or in conjunction with a particular substantive course and are not reflected in the formal curriculum. For example, every year two professors at Boston University Law School asked me to present research sessions in their courses on refugee and asylum law and $\mathrm{EU}$ law. Both of these courses require a research paper, and the professors felt that they got better papers when the students understood research in these areas. This is a useful means of research instruction because it provides the students with a context; however, it has two significant drawbacks: it relies on the interest and cooperation of the professor, and it is not systematic. An alternative model is seen in schools that offer international legal research as a component of advanced legal research. ${ }^{7}$ Examples of these include: Cardozo School of Law, Yale Law School, Fordham University School of Law, Northwestern University School of Law, and Cornell Law School. Some of these schools require advanced legal research for all upper-class students while others offer it as an elective. The advantage of including such instruction in an advanced legal research class required for all upper-class students is that all students get some exposure to international legal research. Finally, some law schools offer courses in international legal research for credit. These include the University of Washington School of Law, ${ }^{8}$ Harvard Law School, ${ }^{9}$ Brooklyn Law School, ${ }^{10}$ Duke University School of Law, ${ }^{11}$ University of Houston Law Center, ${ }^{12}$ Boston University School of Law, ${ }^{13}$ and the University of Virginia School of Law. ${ }^{14}$ Librarians teach all of these courses.

My own experience of introducing instruction in international legal research at Boston University Law School followed an evolutionary path. First, I was asked to teach an international legal research component of an advanced legal research course. Then, having had that experience, I thought that students would be interested in improving their research skills and offered open sessions on particular topics. Next, the law school approved a standalone three-credit international legal research course, which I taught. The following year this course was integrated into a substantive international law course. This evolution from one class to a full course was interesting and 
taught me a number of things about how research, particularly international legal research, is best taught.

As a component of an advanced legal research course, the teaching of "international legal research" is a misnomer. Because the time the teacher is allotted-one lecture-is so limited, she is forced to choose a subject to present. Should she teach treaty research, certainly the most useful thing for students to learn, or should she teach something else? I opted to teach a problem-based class in an attempt to show students what international and foreign questions they might encounter in day-to-day practice. The advantage to this approach is that students can see the potential relevance of the lecture to their future work. It is not hard to think of situations in day-to-day practice where a student might encounter a treaty or need to understand the law of a foreign jurisdiction. I used a child abduction case where the non-custodial parent takes the child to another jurisdiction. I demonstrated in the class how this problem could be approached from a research perspective. The problem with this approach is that there is too much material for such a short period. To actually instill in students a sense of the tools available and a research methodology would require much more time. So, given the limited amount of time available in a single advanced legal research session, it might be best to focus on treaty research. Most students will encounter at least one treaty in their careers, and if they do not take an international law course, they may never even hear the word "treaty" mentioned in any of their other legal courses.

The next format, research lectures offered to students on a voluntary basis, was more or less a failure. The bottom line is that no one is going to take a research course unless he has to. Law students have enough work to do and generally do not see the value in building up their research skills. I, myself, only realized the importance of research once I was actually practicing law. I offered a series of lectures focusing on treaties, the UN, the WTO, commercial arbitration and the EU, some of which supplemented courses offered at Boston University Law School. Attendance was poor even where I tried to get the professor who taught the substantive course to announce my course in his classes. I realized that without a formal link to those courses or an independent mechanism for compelling attendance, there would be little point to the sessions, so I approached my director and asked him to lobby the administration for a course on international legal research. He did so happily and was successful. I presented a proposal together with a syllabus developed with the help of Virginia Wise who has taught international legal research at Harvard as an independent course for a number of years. The proposal was approved, and I proceeded to develop the course.

The course was a success overall; the only drawbacks were that the students taking the course were all third-year students, and there were only seven of them. Third-year students are less likely to need a library-centered 
course for research papers than second year students, so the value of a course that deals with some of the more esoteric subjects-like customary international law-is limited if only directed at third-year students. The course itself was two-and-a-half hours a week. Weekly readings, five problem sets, three writing assignments, and a presentation were required. Over the course of the semester, I introduced researching multilateral treaties, researching bilateral treaties of which the U.S. is a party, customary and other sources of international law, the United Nations, human rights (as an example of UN research plus that of other international entities), trade law, international litigation and arbitration, international business, the EU, common law jurisdictions, and civil law jurisdictions. I attempted to cover all of the sources of public international law, some of the major international institutions, some aspects of private international law, the EU as an example of regional integration, and provide some sense of researching foreign jurisdictions. Students commented that they felt they gained an understanding of the structure inherent in the international system as well as some knowledge of how to research questions with an international dimension.

Although the full-fledged course had many advantages over my earlier attempts, it also presented problems. Because international, foreign, and comparative legal research is an area not taught in the traditional legal research curriculum, there is no textbook. I found that many of the materials I wanted to use could only be reproduced at great expense. Therefore, I put those readings with copyright protection on reserve and created a course pack for those materials without copyright protection. A few publications might serve as textbooks. For example, NYU Law Library's 1998 publication, An Accidental Tourist on the New Frontier, covers a number of topics one might want to include in an international legal research course. The books generated from the AALL-sponsored institutes on foreign and international law can also be reproduced and used as a group to cover quite a number of research areas. ${ }^{15}$ The teacher of a free-standing three-credit course, for example, can comfortably assign readings that cost $\$ 50$ plus; however, if she teaches a one-credit course or integrates her course into another class that also assigns books, she needs to have a text available that is less than $\$ 50$. What is needed is a textbook, complete with problems and with the structure of a traditional legal research course book that can be used to teach international legal research.

Which leads to the next problem-how to ensure that students get practice in the skills they are learning. A problem set, questions created with the purpose of using important research tools, is time consuming to create. Ideally, a problem set is centered on an interesting area of research, uses all the relevant resources, and takes a certain amount of time for the students to finish. Other courses use other models: students can be assigned a pathfinder, forcing them to think of the uses of resources; or there can be an exam. In one 
of my classes, I gave writing assignments where the students started with only a fact pattern. All of these models have their drawbacks: problem sets are repetitive and can be uninteresting; pathfinders do not force the students to use the materials; exams mean the students need never even touch the materials; and writing assignments can be confusing and difficult to grade. Some combination of these models would be ideal, and a good textbook could touch all the bases.

The other problems I encountered were traditional research course problems: generating class discussion and integrating the readings. Because there is no textbook in this area, I focused most of my energy on covering the large amounts of material I was trying to include and devoted little attention to teaching methods that would involve the students more. Helpful in this regard is the portion of this article written by Jean Davis and Victoria Szymczak, which focuses on the methods they have used in teaching international legal research.

My course evolved one step further. Because I felt that the course was not reaching the students who were most likely to do research in this area, the secondyear students on the Journal of International Law, and because I hoped to get a larger number of students, I approached a professor who teaches a substantive international law course. We joined his substantive law class and my research class with the intention that it became a requirement for those journal students who had not taken international law in the first year. We proposed our course to the administration, and it was accepted. Our four-credit course met three times a week, and I had the students on one of those days for one hour and twenty minutes. While this format was not completely satisfactory because the substance and research portions of the class functioned independently, it could work quite well with a true introductory class.

The ideal with regard to international legal research is that it continue to be taught by librarians who have an interest in maximizing the use of the collections in their libraries. To legitimize the study of international legal research, however, it needs to be integrated into the formal law school curriculum as a full-credit course. Having one lecture in an advanced legal research course is not adequate. To ensure student participation, it should be either a required portion of a substantive international law course, or required of all students on international journals or participating in an international moot court competition. Finally, some effort should be made to put together a course book complete with problems so that such a course could be taught without the work of improvising an entire syllabus and all the practical course work. Given the extensive offerings of international law at many law schools and the increase of international law journals, there is clearly a need for systematic instruction in researching international law. 


\title{
HOW TO GET STARTED TEACHING FOREIGN AND INTERNATIONAL LEGAL RESEARCH
}

\author{
Katherine Topulos
}

You are faced with the prospect of teaching international and foreign legal research for the first time, either an entire course or several lectures in an advanced legal research class. Where do you begin? This section of the article is based on my experiences teaching a semester-long course meeting once a week on research methods in international, foreign, and comparative law. The class is required for students pursuing an LL.M. degree in international and comparative law at Duke Law School. When such a course is taught for a full semester, there is ample opportunity to cover a wide range of international and foreign legal research topics, from treaties to the European Union, from comparative law to international arbitration. Not so when the teacher is limited to giving a few lectures as part of a larger course and must make decisions about what topics to include based on the rest of the curriculum and student interest.

The course begins with classes on researching international law (how to find treaties, the law of international organizations, etc.), followed by classes on comparative and foreign legal research, and ends with classes on international business transactions and dispute settlement. These last two topics help students pull together research strategies they have learned during the semester because they involve researching a variety of materials, from treaties to the regulations of international organizations (such as the World Trade Organization) to the laws of other jurisdictions.

I used the classic definition of the sources of international law from the Statute of the International Court of Justice as a framework for planning the curriculum. (I was lucky I had the syllabi and advice of my predecessors at Duke to guide me.) Article 38(1) of the Statute states that disputes submitted to the court should be decided by applying treaties, international customs, general principles of law, judicial decisions, and the teachings of international law scholars. ${ }^{16}$

We devote a class early in the semester to learning how to research treaties and other international agreements, the first source in the Statute. Students learn about U.S. sources (such as Treaties in Force), multinational sources (like the United Nations Treaty Series), and prepare a short treaty-finding exercise for class.

The next source of international law listed in the Statute is international custom, in other words, rules that are derived from the general practices of states and international bodies. International practices are documented in a wide variety of sources, including international and national judicial deci- 
sions, state papers, and the documents of international organizations (such as resolutions of the U.N. General Assembly). Classes designed to teach students how to find this information include sessions on U.S. practice in international law (focusing on publications from the Department of State) and the law of international organizations (focusing on the United Nations and the European Union).

The third source of international law listed in the ICJ Statute is general principles common to the major domestic legal systems (for example, the notion of procedural due process). Classes on comparative law in general, as well as on researching specific legal systems, teach students where to find legal materials from other jurisdictions. In addition, students do short (fifteen minute) presentations on the law of a foreign jurisdiction; the presentations include an overview of the legal system, an explanation of the students' research strategies, and the most important sources (in print and electronic formats) a researcher would use to learn about this jurisdiction.

Judicial decisions and teachings of international law scholars are the final sources listed in the Statute. Judicial decisions include those of both international and national courts. In classes on selected international organizations and on foreign and comparative legal research, the students learn how to find decisions of various international tribunals, such as the International Court of Justice and the European Court of Justice (the courts of the U.N. and E.U.) and decisions of national courts (e.g., England and France).

The writings of international law scholars are useful research aids as well as sources of international law. They are especially useful starting points for international legal research. They not only discuss legal issues, but they often provide references to the sources of international law-important since international law is not conveniently indexed and organized.

Secondary sources are good starting points for foreign legal research as well. They explain the basic arrangement of a legal system so researchers will know where to look for the documents they need and be able to understand their significance once found. Secondary sources in the vernacular will acquaint researchers with the specialized legal vocabulary they will need to do research successfully. Included on the research guides I hand out in class are the titles of some of the most important treatises for each subject, along with advice for finding others (such as the most efficient subject searches in the online catalog).

Students need to know that they should not limit themselves to the law library when researching international and foreign law. To teach them about other resources on the Duke campus, we visit the international documents collection in our main library. That library is a depository for the U.S. and the European Union and has a comprehensive collection of U.N. documents. I also 
introduce them to less obvious resources on campus, especially "people" resources. For example, I tell them about bibliographers with area specialties, such as East Asian, Slavic, and Latin American studies, who can help them with their research projects.

Assignments are designed to teach students to use both print and electronic sources. This year there were several ungraded exercises that we went over in class, including three document-finding exercises designed to teach students to find treaties, U.N., and E.U. publications. The graded assignments included two short projects, an evaluation of the web site of an international organization, a class presentation on a foreign legal system, and an annotated bibliography (about ten to fifteen pages) on some aspect of international law or about a foreign legal system. The final paper was organized into three sections: a concise abstract of the topic, a discussion of research methodology, and an annotated bibliography of sources. Students enjoy the chance for class participation and the opportunity to work on topics that we do not cover in class.

A new teacher of international and foreign legal research should not attempt to reinvent the wheel. There are many resources that can help the novice learn about the most useful tools for foreign and international legal research as well as help him or her to design a syllabus. During the 1990s, the American Association of Law Libraries (AALL) sponsored a series of five institutes designed to train foreign and international law librarians. The institutes focused on a variety of topics, from foreign and international law to transnational legal transactions and international business law. Each institute was memorialized by a book with articles written by instructors at the institute. ${ }^{17}$ These books provide a brief overview of the substantive issues as well as a wealth of bibliographical sources.

Another resource is the Teaching Foreign, Comparative and International Legal Research Interest Group of the Foreign, Comparative and International Law Special Interest Section (FCIL-SIS) of AALL. This group, which provides a forum for exchanging ideas about teaching international and foreign legal research, meets each year during the AALL annual meeting to talk about what works (and what does not), share activities and exercises that have been particularly effective, and discuss common problems and issues. Members range from directors to new librarians, and everyone interested in the subject is welcome to attend the meetings. The FCIL-SIS member, Christine Corcos, Associate Professor of Law at the LSU Law Center, has created a web page that includes both syllabi and research guides for international, foreign and comparative law research. ${ }^{18}$ 


\title{
TEACHING TECHNIQUES AND ACTIVITIES FOR AN INTERNATIONAL AND FOREIGN LAW RESEARCH SEMINAR
}

\author{
Jean Davis \\ Victoria Szymczak
}

The Davis and Szymczak Credo: Master your material. Be a dynamic, entertaining speaker. Encourage class participation. Use hypotheticals featuring your students. Devise group exercises and gaming activities.

The Students' Credo: Snacks are good!

Our International and Foreign Law Research seminar requires each student's active involvement. We engage pupils through various teaching techniques, including visits to large research libraries, presentations by seminar participants, guest lectures by energetic colleagues, and our popular, interactive games. ${ }^{19}$

\section{Guidelines for Assignments}

In Fall 2000, we required mid-semester presentations on foreign legal systems and end-of-term research guides on international organizations. In our 1998, 1999 and 2000 IFLR seminars, students understood and ably performed these requirements. The key-post instructional guidelines for each assignment on your course page. If possible, train student assistants to hold "office hours" in the library's IFLR collection during the weeks preceding project deadlines. (Anticipate temporary lulls in patrons and assign the student worker a research task, such as evaluating new acquisitions for a bibliography.)

\section{Tours of Research Libraries}

Before this semester's presentations on foreign legal systems, our class toured New York University School of Law Library. Mirela Roznovschi and Jeanne Rehberg highlighted subject-oriented sets covering many jurisdictions and sources focusing on students' countries. We asked students to compare the print Tax and Commercial Laws of the World (available at New York University School of Law) to Foreign Tax and Commercial Laws on CD$R O M$ (available at Brooklyn Law School). Students also searched the online version of the Index to Foreign Legal Periodicals: A Subject Index to Selected International and Comparative Law Periodicals and Collections of Essays. Following the tour, we remained and as students used this opportunity to 
evaluate hard-to-find materials on their jurisdictions. As a result, students who returned to New York University School of Law Library throughout the semester were more confident researchers.

\section{Student Presentations}

Prior to addressing the class, Fall 2000 students attended and enjoyed a Corel Presentations training session led by Brooklyn Law School's software trainer, Barry Reichman. He taught the students how to create slide shows, to link Internet sites to slides, and to add graphics and sounds to slides. We will invite Barry to return for a 2001 command performance.

Building on their training, most students chose to create slides on researching a legal topic in a foreign jurisdiction. Displaying slides and linking to web sites is time-consuming. In the classes preceding presentations, instructors must emphasize that each student will have only fifteen minutes to speak. If the most useful web site is inaccessible, the presentation goes on. If a student's laptop freezes, the presentation continues. We frequently remind students: "You are your own best visual!" Our warnings pay off. When the library laptop crashed as one student linked from a slide to the Europa web site, this student directed the audience to a photocopy of the web page and continued his analysis. Meanwhile, Victoria addressed the technology problem.

If students wish to use their laptops for presentations, insist that they (1) schedule advance appointments to test equipment and slides in the classroom and (2) arrive twenty minutes prior to the designated class to conduct a final run-through. On presentation dates, schedule these students first, or immediately after a mid-class break. You do not want to lose class time as they set up. Some students might prefer to distribute handouts and to display a few web sites with the library's equipment. In advance, require these students to submit the Internet addresses. Bookmark the sites on the library's laptop.

\section{Guest Speakers}

Invite guest speakers to address your class. Tempt speakers with dining adventures to follow their appearances. This semester, Jeanne Rehberg, Special Assistant to the Director/Reference Librarian for International and For-

eign Law at New York University School of Law Library, ${ }^{20}$ illustrated GATT/WTO research with Internet and depository sources. Students were thrilled to meet the editor of their textbook, Accidental Tourist on the New Frontier: An Introductory Guide to Global Legal Research.$^{21}$ In fall 1999, Kate McLeod, Associate Law Librarian for Public Services at Fordham University School of Law Library, honed our pupils' European Union research 
skills. $^{22}$ Emphasize that students must prepare for classes featuring guest lecturers. We take note of and commend pupils who interact with a visiting information professional. We also credit active class participation.

\section{Library Exercises}

Course evaluations reveal that students expect a research seminar to begin with a library tour and to include many "hands-on" exercises throughout the semester. Students prefer to prowl the stacks when completing exercises, but this might not be feasible if one has a large enrollment. This semester, Victoria conducted a Canadian legal research exercise in the library's foreign law collection area. Students used the Canadian Abridgment to "note up" a case and to find articles on international trade. Weeks in advance, Victoria posted notices in the library announcing the upcoming session and warning of possible disruptions.

In our Fall 2000 opening class, each student "selected a stumper" from a grab bag. The stumper required use of a designated research tool, such as Treaties in Force: A List of Treaties and Other International Acts of the United States in Force on January $1,[] .{ }^{23}$ During the library tour in the following class, we highlighted the sources that students used to answer the stumpers and asked each student how a particular tool led to an answer.

\section{Interactive Games}

Played in teams, Mission Made Possible creates bonds among students and stimulates interest in our course. Before our first class meets, we ask students to complete a public international law reading. During the first class, we play Mission Made Possible. We base our questions on the reading assignment. As the game progresses, we highlight pertinent sources.

We knew that our end-of-semester adaptation of "Who Wants To Be a Millionaire. ..." was a hit when students wished to continue playing through the mid-class break. "So You Want To Pay Off Your Law School Loans. . . ." was our send-off. Chairs ringed the room. All eyes focused on the "hot seat" in the center of the circle. The theme to "Mission Impossible" punctuated our explanation of the rules. Qualifying and game questions covered topics discussed throughout the semester. During the game, we allowed each player to choose two of the following "life lines": access one Internet site, review sources on the book cart, ${ }^{24}$ ask the professors to eliminate two answers, or poll the class. Students urged each contestant to consult the class. They lobbied for a fifth option-to call a librarian. A player had three minutes to answer a question. We encouraged students to explain their responses. When a contestant did not select the correct answer, we described the source(s) that 
would have led to a better response. Some questions were tough. We did not want one student to monopolize the hot seat. Once a student had completed a turn, the student could no longer answer qualifying questions. The students raved about the game; it combined learning and laughter.

\section{Learning from Colleagues}

We benefit from collaborating with enthusiastic, skilled colleagues. Instructing Palmer School of Library and Information Science students with Radu Popa, Jeanne Rehberg, and Mirela Roznovschi of New York University School of Law Library sharpens our international law research skills. In partnership with Marci Hoffman, International and Foreign Law Librarian at Georgetown University Law Library, we maintain a list of Internet sources described in the April 2000 presentation, "A New Vision for International Law Instruction: Changing Roles/Relationships of Professors, Librarians and Students."25

For creative approaches, we review the web page of the FCIL-SIS interest group on teaching foreign and international law research. ${ }^{26}$ Combing legal periodicals also yields pearls like Laura J. Orr-Waters' article, "Teaching English Legal Research Using the Citation Method."27 Our version of OrrWaters' discussion questions appears on the Fall 2000 course home page. Attending vendor training sessions also increases our understanding of new sources. We recommend Stephanie Stoudt-Hansen's and Michele Spencer's presentation, "The British Legal System and United Kingdom Materials on Westlaw ${ }^{\circledR}$." On July 15, 2001, Victoria and John Nann ${ }^{28}$ will demonstrate many techniques at their fast-paced, fun AALL Annual Meeting program: "Mastering THE MATRIX: Teaching with Technology." They will then lead a discussion at the AALL FCIL-SIS "teaching" interest group meeting.

The authors hope that the sources, techniques, and experiences described in this article will aid others in developing international and foreign law research training sessions and courses.

\section{NOTES}

1. Roundtable on the Teaching of International Law, 85 Am. Soc'y Int'1. L. Proc. 102 (1991).

2. Louis F. Del Duca and Vanessa P. Sciarra, Developing Cross-Border Practice Rules: Challenges and Opportunities for Legal Education, 21 Fordham Int'l. L. J. 1109,1123 (1998).

3. John A. Barrett, International Legal Education in U.S. Law Schools: Plenty of Offerings but too few Students, 31 Int'1. Law. 845 (1997).

4. Joyce Manna Janto \& Lucinda D. Harrison-Cox, Teaching Legal Research: Past and Present, 84 Law Libr. J. 281, 283 (1992). 
5. According to Arthur Miller, legal research is being taught "in a crazy quilt, half-assed way." He says, "I view that as a tremendous vacuum that you people [law librarians] should just go out and seize." Towards a Renaissance in Law Librarianship (Richard A. Danner ed., 1997) at 41.

6. Modern Technology and Its Effect on Research and Communication, $86 \mathrm{Am}$. Soc. Int'1. L. Proc. 604 (1992).

7. This model is recommended by Lucia Ann Silecchia, Designing and Teaching Advanced Legal Research and Writing Courses, 33 Duq. L. Rev. 203 (1995).

8. Mary A. Hotchkiss, University of Washington School of Law, Course Home Pages, International and Foreign Research <http:/www.law.washington.edu/ courses/hotchkiss/E579A/syllabus.html>.

9. Virginia Wise, Harvard Law School, Courses by Professor, Legal Research: International, Foreign and Comparative <http:/www.law.harvard.edu/students/catalog/ catalog.php?op=show\&id=303>.

10. Jean Davis \& Victoria Szymczak, Brooklyn Law School, Introduction to International and Foreign Law Research <http:/www.wcbcourses.com/wcb/schools/ LEXIS/law06/vszymcza/19/>.

11. Katherine Topulos, Duke University School of Law, Course Home Pages, Research Methods in International, Foreign, and Comparative Law <http://www.law. duke.edu/curriculum/courseHomepages/380_01>.

12. Timothy F. Mulligan, University of Houston Law Center, Research in Foreign and International Law <http:/www.law.uh.edu/librarians/tmulligan/f\&isyllabus 2001 . html>.

13. Daniel G. Partan \& Stefanie Weigmann, Boston University School of Law, International and Foreign Law in United States Courts.

14. Xinh Luu, University of Virginia School of Law, Course Home Pages, International and Foreign Legal Research.

15. See further discussion in Katherine Topulos' section below where full citations are referenced.

16. For a copy of the syllabus see supra note 11.

17. The books, all published by Oceana, are titled Introduction to Foreign Legal Systems (Richard A. Danner \& Marie-Louise H. Bernal eds., 1994); Introduction to International Organizations (Lyonette Louis-Jacques \& Jeanne S. Korman eds., 1996); Introduction to Transnational Legal Transactions (Marylin J. Raisch \& Roberta I. Shaffer eds., 1995); Introduction to International Business Law: Legal Transactions in a Global Economy (Gitelle Seer \& Maria I. Smolka-Day eds., 1996); and Contemporary Practice of Public International Law (Ellen G. Schaffer \& Randall J. Snyder eds., 1997).

18. You can link to this web page from the FCIL-SIS site <http:/www.lawsch.uga. edu/pcil/pcil.html $>$ by clicking on "Collection of FCIL-related Course Descriptions and Syllabi."

19. Our International and Foreign Law Research course home page appears at <http://www.webcourses.com/web/schools/LEXIS/law06/vszymcza/19/>. This site includes an introductory slide show, the "Mission Made Possible" game, and the "U.N.derstanding" game. We further discuss our classroom games in a later section of this article. To view the slide show, select: Handouts and Links > Links: 
Introduction to the Course. To access the games, select: Handouts and Links > Lessons: Research Skills. Regarding Millennium Madness game category, "National Pride": audio files for national anthems are not loaded on Brooklyn Law School Library's server. See <http:/www.imagesoft.net/flags/flags.html> (flag images and national anthems), <http://www.fg-a.com/flags.htm $>$ (flag images), and $<$ http://www.lengua. com/hymnen.htm> (national anthems). The course finale, "So You Want To Pay Off Your Law School Loans ...." is available through $<$ http:/www.idrive.com/vszymczak/ files/Shared/>. Check off a file to download and click on: Download. Click on the file name. You need Corel Presentations software to view this game (qualifying questions: qualifying.shw and game: payoff.shw). The first time a visitor downloads a file with the extension shw, the browser offers the choices: Pick App or Save File. To open the file, select: Pick App > Browse > Corel Presentations. To save the file, select: Save it to disk and choose the folder on your computer in which you want to save the file.

20. Ms. Rehberg supervises the library's WTO depository collection and is the author of WTO/GATT Research <http:/www.law.nyu.edu/library/wto gatt.html>.

21. Jeanne Rehberg and Radu D. Popa, eds., 1998.

22. Previously, Ms. McLeod was our colleague in the Joint International Law Project (JILP) among Brooklyn Law School, City University of New York School of Law, Queens College, Flushing, and New York Law School. In the JILP program, New York Law School collects the majority of European Union materials. Ms. McLeod is an expert EU researcher.

23. Treaty Affairs Staff, Office of the Legal Adviser, U.S. Dept. of State, Pub. No. 9434

24. Sources included Introduction to Transnational Legal Transactions (Marylin J. Raisch \& Roberta I. Shaffer, eds., 1995) and the International Bar Association, I.B.A. Rules on the Taking of Evidence in International Commercial Arbitration (1999).

25. See "A New Vision for International Law Instruction: Changing Roles/Relationships of Professors, Librarians and Students," at $<$ http://brkl.brooklaw.edu/screens/ pubs.html $>$ and at <http://www.ll.georgetown.edu/intl/presentations/teachingintlaw. htm>.

26. See supra note 18. Christine Corcos (ccorcos@isu.edu) welcomes submissions (syllabi, research guides, and exercises) for this page.

27. Persp.: Teaching Legal Res. \& Writing, Spring 1998, at 108.

28. Mr. Nann is Educational Technology Specialist/Legal Reference Librarian at Boston College Law Library. 